\title{
European and Cameroonian scholarship on ethnicity and the making of identities in Cameroon: colonial and post-colonial trails
}

\author{
Emmanuel Yenshu Vubo \\ Department of Sociology and Anthropology, Faculty of Social and Management \\ Sciences, University of Buea, Cameroon
}

\begin{abstract}
Relations between colonial and post-colonial studies in and on Cameroon have been both continuous and discontinuous. As reflected in the domains of historiography and social anthropology, this has impacted on ethnic self-representations and popular labeling. This paper examines contrasting drives that have led to a replication of colonial redefinitions of ethnicity and how this informs current discussions on ethnicity in Cameroon. The argument is that certain research works have informed or substantially influenced the identity question when one aknowledges that the colonial period is a bench mark epoch in the establishment of certain categories of ethnic perception. Although substantially deconstructed at the scientific level, these categories have survived and continue to influence social categories of perception that become common sense intrusions (what Bourdieu called doxa) into social science.
\end{abstract}

Key words: colonialism, ethnicity, identity, perceptions, scholarship

\section{Introduction}

The colonial encounter, which has shaped African history and its destiny in varying ways, was also an epistemic moment, a moment of knowledge about people, shaping "knowledge" about peoples and reworking self-identifications. It was a new moment in social knowledge which, in general, shaped views about others following the development of the dichotomous categories of Self and Other. One of the offshoots of this encounter was the development of a hybrid discipline that occupied an ambiguous position between science and the administrative practice of colonial rule, that is, colonial anthropology, an applied social science whose role was to assist in colonial administration. If anthropology has to preserve its older meaning of "knowledge of the other" by European modernity, colonialism was a moment when the Other erupted into European or EuroAmerican intellectual schemes in a systematic manner and in a style that was both systemic and practical. It differed significantly from the curious accounts of explorers, mis- 
sionaries, travelers and others in that it claimed a scientific status as it sought to gather facts, theorize and generalize. In a practical sense it was essentially meant to produce practically usefully knowledge. One of its main preoccupations was with the identification of ethnic groups colonizing powers come into contact with. The curiosity aspect of the identification process was that it was also one of classification structured around colonizer and colonized, on the one hand, and between the diversity of the colonized, on the other. It was a new vision and division of the world (to speak in the language of Bourdieu) of the colonized world. What are its categories in terms of the identification and classification of peoples it was confronted with? How did these become not only part of an intellectual scheme but also an important part of popular self-perceptions (identification and classifications) in relation to others? What attempts have been made at deconstruction? What are the surviving legacies?

This paper examines these questions in relation to colonial anthropology's treatment of identities in Cameroon, their legacies and attempts at deconstructing the categories generated by this type of scholarship in the post-colonial period. It also examines the context within which these developments take place taking into consideration the intellectual contacts between European and local Cameroonian scholarship in terms of continuity and discontinuity. As a first step, an attempt is made at a general description of the invention of ethnic categories and categorizations/classifications by colonial administrative practice in the western highlands area otherwise known as Grassfields during the British mandate period. The next step examines the role of colonial scholarship in this regard as well as its heritage. This will enable us to analyze the work of deconstruction that has been undertaken by a generation that one can describe as scholastic or scientific anthropology starting in the I970s. A case study is presented of problematic identity that was generated in the British colonial era in the Grassfields, namely the Chamba-ness of Bali Nyonga and the question of the so-called Bamenda Tikar. This work draws on a previous book review by the author that had hinted only in passing at some of the issues raised here and tries to update those issues raised.

\section{Theoretical background: Colonial Administrator-Scholars and their Heritage}

The earliest framework for understanding the peopling of Cameroon was developed during the colonial period as a handmaid to the colonial management of ethnic diversity. During this period one could observe an attempt to classify peoples according to the state of anthropological research of the time. As such, there was a grand division between Sudanic, Bantu and pigmy peoples that has survived largely unaltered into the post colonial period. Using historical traditions elaborated by colonial officials and researchers at the service of the colonial administration (which even consulted them on matters of policy), British authorities in the Southern Cameroons inspired standardized narratives that became the basis of categorizations that served more their political interests than explained any form of ethnic realities.

The historical impulse, widespread in this area, that has received a century of encouragement from colonial and post-colonial administrators and researchers, is to ac- 
count for identities (however fragile, shifting and situationally defined) in terms of historical origins. These origins were usually elsewhere (Fowler and Zeitlyn, r996: 8).

It is in this sense that Rene Otayek (200r: 8) affirms that:

le moment colonial consacre, en effet, une sorte d'assimilation réciproque entre militaires, administrateurs civils et anthropologues autour d'un objectif commun : mieux connaître les sociétés conquises pour mieux les gouverner et fonder une 'praxis coloniale' en établissant des liens de causalité commune et l'action./The colonial moment consequently sanctioned a sort of reciprocal compression of roles between military officials, civil administrators and anthropologists towards a common goal. This was to better understand conquered societies in order to better govern them and establish a sort of colonial action that integrated common causes and action.

Amin (1998: 56) has associated this process with the reorganization of colonial territories and the search for intermediary chiefs in the need "to gain control of vast areas, often disorganized following the decline of the slave trade" in the "absence of states, or of a dependent or feudal class." What was at work was an attempt by the "administrators and the military, poor amateur anthropologists" trying to invent a tribe (ibid.). The colonial practice in the area in question tended to resemble in all respects the practice in other British colonies where "the anthropology written by full-time political officers, presumably reflecting their administrative inclinations" was of some significance (Kuklick 1978: 101). In this case the priority was to "restructure African societies for administrative convenience" (ibid.) by ensuring that "district boundaries were fixed to enclose areas of cultural and ethnic diversity" (de Souza \& Porter 1974:4I). The use of oral traditions, with all the inconveniences of this approach, in the design of colonial administrative boundaries or the recognition of hierarchy has also been reported for the British of the Gold Coast. "The British method for establishing effective control in the Northern Territories of the Gold Coast revolved around their notion of what constituted a legitimate 'tribe'. A central feature of their policy was to organize local societies around British conceptions of pre-colonial 'tribal' structures" (Casentini 2008 2; cf. also Kuklick I978: 106107). Maupeu (1990) reports similar situations in Kenya where historical narratives were manipulated to fashion new ethnic identity awareness but now with the collaboration of Christian missionaries.

In the Western Grassfields of Cameroon, then under the British rule League of $\mathrm{Na}$ tions mandate, authorities resorted to a two dimensional classification. Firstly, there was a division between supposed Bantu peoples with origins in the south (and even said to have migrated from the Congo basin) and peoples composed of migrants to the North (Chamba and Tikar). The latter bore elements of the Hamitic hypothesis without this being explicitly declared. This “ideological perversion called the 'Hamitic hypothesis'... claimed to explain all signs of civilization in Bantu Africa - from monotheism to the use of iron and other material artifacts to the development of statecraft" (Mamdani 2002: 
35). "Every sign of 'progress' on the Dark Content was now taken as evidence of a civilizing influence of an outsider race. This race of civilizers, it was said, were Caucasians who were black in color without being Negroid in race. Thus were born the Hamites of Africa, separated from the Bantu, or so-called real Africans" (ibid.: 79; cf. also Dika Akwa 1982: 15-34). Scholarship about peoples in the areas that currently constitute Northern Cameroon and Nigeria, maintained that this division was reflected in history of origins to the East, either in the Nile Valley, the Middle East or the Arabian peninsular. One version widely espoused was the Kisra legend which brought the Chamba and others from the East. In the Great Lakes region of East Africa, the Hamitic hypothesis would equally serve as the basis of colonial divisions and colonially sustained relations of domination between Tutsi (supposed Hamitic) and Hutu (Bantu) that were to be the source of bitterness far into the post-colonial period (Chrétien [1985] 1999: 129-164).

As a second step, the groups with northern origins (Chamba and Tikar) were afforded a privileged position in the hierarchy of ethnic classifications as a high status people while the peoples of southern origins (Widekum) occupied a lower position. This derived from two models often used by the colonial anthropology to explain relationships between peoples in Cameroon, namely a conquest-assimilation model and a genealogical model. The conquest model, which could have been partially valid if the processes of conquest could be reconstituted, argued that the ethnic composition of peoples as they were met by the colonizer was the product of endless wars between tribes that led to the subjection of vanquished peoples by superior peoples. Chamba presence in the Cameroon Grassfields in the igth century, with its sporadic and, sometimes, luckless attacks on local peoples, created an impression among some peoples (naming, adoption of some cultural practices) to the extent that the Chamba culture was perceived as a high culture at least towards the end of the igth century. For a long time historians mistook this for conquest to the extent that colonial administrators fostered it through the advent of empire and sub-imperialism that Bali Nyong'a was granted during the German protectorate (O' Neil, 1996). As we will see later, it was this model that was to inform the attitudes of colonial officers towards peoples.

The genealogical model used the idiom of kinship to express the nature of relations between peoples. In order to demarcate administrative boundary units of the Indirect Rule framework, the authorities resorted to a certain genetic anthropology which quickly established itself becoming the model of scholarship on the peopling of this region and subsequent ethnic classifications. Fowler and Zeitlyn argue that this "origin fetishism" served as the basis for the "construction of identity in the colonial period and the regalisation of chieftaincy" (op. cit.: 7) wherein "[c]olonial officers conducted research with a view to establishing a hierarchy of chiefs and structures of tax collection" (ibid.: 9). The metaphor of kinship, itself an integral part of popular discourses and commonplace language (as is often the case with that of consanguinity) was the corollary of resorting to this mode of ethnogenesis. Ethnic groups were presented as related to each other in terms of kinship and descent. This model of ethnogenesis has remained attractive for the people concerned and, recently, the Bamileke, this category being in itself problematic. 
As a result, historical traditions adjusted themselves to fit into this model and categories of colonial historiography under the imperative of positioning within the hierarchy instituted by indirect rule. This was as much related to the question of paramountcy between chiefs within the Native Authority framework as to the hierarchy of ethnic classifications. Chiefs were the principal agents in this dynamic as they sought to define their ethnic groups within this classificatory scheme and to get themselves appointed. The categories known as Chamba, because of their position as invaders during some periods of their history, and the so-called Tikar, due to their supposed "northern" origins and probable "Hamitic" pedigree', were thus considered to be of higher status.

These trends are reflected in colonial reports. During the reorganization of the $\mathrm{Na}$ tive Authorities in the late I940s efforts were made to keep Bali-Nyong'a away from their so-called Widekum neighbours on the basis of their origins and animosity in the precolonial and German periods. In a correspondence to the Resident of the Cameroons Province on 12 th March 1948 the Divisional Officer for the Bamenda Division remarked that:

The Balis [i.e. Bali Nyong'a] alone are of Chamba origin. They occupy an island at the centre of the Widekum migration, and the units of this migration were their vassals when the Germans first occupied Bamenda ${ }^{2}$.

The isolation of Bali-Nyong'a was also extended to the relation with the so-called Tikar groups. The Divisional officer reported that "Bali too were used to subdue the Tikar tribes, and if they have to some extent forgiven, they have not forgotten, nor have the still tactless and arrogant Bali peoples helped them to forget" (ibid.). The senior district officer, F.R. Kay reports that the Fon of Nso indicated the opposition of his people to being in one Native Authority area with Bali Nyong'a because "[a]ncient history and hatreds are too strong... and ancient history is reinforced by modern jealousy" 3 . In addition to these problems between the Bali, on the one hand, and the so-called Tikar and Widekum on the other, there were also conscious attempts to differentiate so-called Tikar and non-Tikar elements on the basis of the superior organization of the former, a legacy of a pseudo-hamitic hypothesis advanced as early as 1926 by the divisional officer Hawkesworth (Yenshu Vubo, 200I; Yenshu Vubo and Ngwa, 2001). All else, ranging from social organization to adaptation to modernity, was then judged in relation to so-called Tikar organization4. The projected reordering of the Native Authorities was to carve out a "big Tikar block" to which Chamba and Widekum elements would be added, and then several other blocks in which Tikar elements would play a central roles. That is why the divisional officer recommended that "every possible contact with the Tikars must be encouraged

Hawksworth, E. C. 1926. Assessment Report on Bafut Tribal Area, National Archives, Buea.

2 Letter No. 2575/17 of I2th March 1948 from the Divisional officer, Bamenda Division to the Resident Cameroon.

3 Report on Bafut, Banso, Ndop federation as appendix to Native Authority and Court Reforms: Bamenda South Eastern Federation

4 See in this regard correspondence No. NA 2414/36 of 2oth September 1948 on the South Western Federation.

5 Chief Commissioner's inspection notes. 


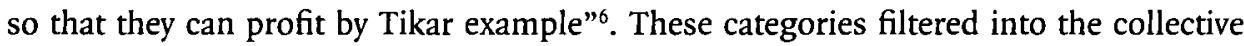
psyche as people came to see themselves as falling into one of these grand blocks. Their survival as part of the imaginary has been largely a result of their inscription in primary and secondary school text books and as part of the teaching and learning corpus far into the post-colonial period, despite considerable energies that have gone into discrediting these categories. It is, therefore, still common to find people still referring to themselves as Tikar to mean superior peoples. This is still reflected in introductory sections of books and theses by young students who have taken this classification to be actual British colonial authorities were not alone in this type of strategy. According to Amselle, in the French western Sudan, the colonial had also resorted to a system of indirect administration that lasted until independence:

...un système d' "administration indirecte" qui perdure jusqu'à l'indépendance, même si officiellement de 1907 à 1917, dans la "politique des races" impulsée par Ponty, on lui substitue un système d'administration directe. La pénurie de personnel métropolitain contraint, en effet, les commandants de cercle de recourir aux bonnes offices des chefs de villages et de chefs de canton, seuls capables de faire régner l'ordre, de rendre justice, de recenser les populations et de collecter les impôts/a system of indirect administration that had a long duration, even if officially between 1907 and 1917 it had been substituted by a direct system of administration within Ponty's racial policy. The scarcity in personnel from the metropolis consequently obliged district officers to use the services of village heads and canton heads, who alone could keep order, administer justice, do head counting and collect taxes (Amselle, 1990: 239).

In order to identify these "chefs de race/chiefs with a pedigree", uncontested in terms of legitimacy and with an informed capacity to govern, the French colonial authorities had to undertake a historical evaluation with some sort of racial lens: "faire l'historique de chaque canton et donc des races qui la compose"/reconstruct the history of each canton and consequently its constituent races (ibid.: 5) -, the overriding motive in any case being political rather than scientific. The result was a modification of historical narratives and the stabilization/crystallization of identities.

Conduit de manière obstinée et méthodique, ce travail d'imposition identitaire et de catégorisation ethnique aura pour résultats de figer des identités qui préexistaient fréquemment à la conquête européenne mais qui se caractérisaient par leur caractère fluide, fluctuant, labile/Carried out in a dogged and methodical way, this work of identity imposition and ethnic classification has had the effect of crystallizing identities that existed prior to European conquest but which were fluid, fluctuating... (Otayek, op. cit.: 5). 
A resultant tradition that took up the narratives at face value thus created the rather complex situation that one finds today. This is reflected in the persistence of the ethnic labels thus created.

With independence, the work of colonial anthropology came to an end but the activities of data collection, analysis and publication spilled over into the new era, carrying with them, the former categories, concepts and theoretical models that were to emerge as a paradigm. This continued for almost a decade after or even beyond. In this register, colonial anthropologists completed their work with publications that contained information collected during the colonial period for administrative purposes. This is where we situate some of the publications of some of the scholars who had been at the service of the colonial administration (Jeffreys, 1972; Chilver and Kaberry, 1960, 1967b, 1980, 1970; Kaberry, 1963). These were more descriptive presentations with a large dose of the exotic and in the tradition of archaism reminiscent of an outmoded anthropology. For the most part no attention was paid to theoretical discussions when it came to anthropological data. Its greatest merit lay in the fact that it was a first platform that brought together European scholars and Cameroonians even if the latter were very small in number. Not only did it see the publication of the works of European scholars but it also made it possible for African voices or points of view to be known. It was not until late in the rg6os and 1970s that Cameroonians were trained in anthropology and related domains of history (Titi Nwel I989, Fokwang 2005, Nkwi and Socpa 2007). This early crop of indigenous intellectuals was attracted to the colonial categories, this being the only available frame of reference. That is why historical background information on their works took the categories of colonial anthropology and history for dogma. This uncritical attitude is reflected in the works of Nkwi (1973, 1976, 1982, 1987), Aletum Tabuwe (1971, 1973) and Emmanuel Ghomsi (1972). It is also reflected in Nkwi's section of a co-authored work (Nkwi and Warnier 1982) which is a simple reproduction of a scheme traced by colonial anthropology and historiography. A presentation to the 1973 Leo Frobenius conference of Yaoundé (Nkwi, I974) on the origins of Kom matrilineal institutions, which should have been an eye-opener because it posed the problem question of the contradiction between claims of ethnogenesis in Tikar country and institutions different from the Tikar proper, failed to make the innovative point, trapped as it was within the mythical model.

\section{Deconstruction and continuity: Academic Anthropology and Historiography Interrogates the Colonial Heritage}

In-so-far as ethnicity and identities studies are concerned, academic anthropology, a field that was markedly different from colonial anthropology, came to Cameroon partly through the establishment of the University of Yaoundé shortly after independence and partly through the interest shown by scholars of western European and American origins. The theses produced and the subsequent publications either markedly altered the scientific perceptions of identities and ethnicities or continued to reproduce the colonial model in an orthodox manner. One monograph of interest is Warnier's thesis (Warnier 1975) which situates the chiefdom of Mankon within its "regional setting" accounting 
for its development in relation to long-distance trade rather than population movements and alleged kinship ties. This theme has been elaborated in a series of studies in a model that combines linguistics, material culture and archaeology and overtly challenges the perception of identities in the Cameroon Grassfields (Warnier, 1984 : 395-396). His individual and collaborative research projects that span two decades arrives at the following conclusions: the area under question has been occupied for a several millennia and the current inhabitants are the descendents of this ancient stock; the economy of regional exchange was a critical factor in the development of the communities and the relations between them; the latter were not closed entities as they exchanged values but were also constantly recomposing with the movement of what he termed "floating populations"; as a result, the communities were composite in character rather than homogeneous and could not lay claim to single origins and identities; the outlook, as a result, was therefore cosmopolitan rather than narrow as one would attribute to the so-called tribal mentality (Warnier, I985: 306).

Some of the positions held by Warnier are equally present in the works of Tardits (1960, 198I) who developed a regional approach to the understanding of the Grassfields although this is not reflected in his comprehensive study of the Bamum (Tardits, I980). Rowlands (1978) buttressed the argument on the role of regional exchange and the idea of material forces playing a central role in the development of individual communities in themselves and in relation to others. In the same way, Barbier deconstructed the arbitrary distinction between the so-called "Bamileke" (Eastern Grassfields) with neighbouring peoples to the south, this distinction having been taken for granted. This approach widened the scope of research on the people of this area, especially in relation to others outside their immediate geo-ecological niche in a perspective that can be labelled as transethnic (Barbier I98I). In this regard, the oral traditions that link people to others outside the Grassfields will be indicative of continuing relationships that have gone on within Braudel's longue durée, without this implying ethnogenesis and shared identities.

The contribution of linguists in this regard, as Barbier (1978:52) had hinted, has been of capital importance. The collection on Cameroon's Bantu Languages edited by Greenberg as well as Hyman and Voorhoeve's conferences (1974, 1980) on Grassfields Bantu languages resituated the latter within the larger Bantu family as Barbier (1978) had hoped, paving the way for a more critical discussion that moved away from the narrow frame of local isolated, inward looking identities. Above all, the 1973 Paris conference of the CNRS (Centre Nationale de la Recherche Scientifique) - the French research agency - edited by Claude Tardits and published in $198 \mathrm{I}$, provided the critical forum not only for understanding the contribution of anthropology to history but the starting point for re-examining conceptions of identities and ethnicities as informed by colonial historiography and ethnography. The critical insights of Chilver which were already expressed in a 1963 article with Kaberry (Chilver and Kaberry, 1963) found their full expression in this forum. Not only did she instigate a definitive break from the colonial categories but, using a purely logico-empirical approach, continued to collect evidence that would make a scientific return to the latter impossible. In a personal communication she even con- 
fesses to a "déformation professionnelle" arising from early medieval studies of the peripheries of mainland Europe combined with [an] upbringing in a family of Irish folklorists" as well as "being hesitant about what [her] colleagues [had] dubbed 'the English mania for migrations' and [having come] to read older sources... in terms of the intellectual fashions of the times" (personal communication 6/5/r996). She even thought that she might be "probably as guilty as the others" (Chilver, 1996: 107). It is in this regard, that she became an important reference for the variety of sources (manuscripts, typed mimeograph, published books) for many a local researcher and took pleasure in discussing critical issues and field notes from a distance. She was also instrumental in arguing for "a better alternative" that should incorporate "the linguistic evidence and its interpretation, such evidence as we have from archaeology, palaeobotany and biogeography, climatic records, even equine veterinary science. A life work, too late for [her] to start" (ibid.: Io8).

Although Chilver started as the administrator of colonial social science funds, she achieved the exceptional feat of self-realization through critical re-examination within anthropology which is captured in the French word dépaysement (a going out of oneself to study the Other) without which a true anthropology cannot be possible. The right metaphor in her situation was that of "game warden" (administrator of research funds and official in-charge of building institutions charged with colonial anthropology) "turned poacher" (an active agent in a deconstruction-revision of the categories which this brand of social science had developed) (Ardener, I996: xii). She can be said to be the best contact point in the Euro-African encounter in Cameroon studies on the Grassfields ("[occupying] a niche in [the country's] history")?

The growth of archaeological research coupled with an interest in ethnolinguistics by European scholars continued to reshape the understanding of identities in other parts of the country. However, one can observe an apparent discontinuity between the "scientific academic" approach inaugurated by Warnier and others and the new generations that have shown no interest in questioning colonial categories along the same lines. One also sees the successful continuity of Chilver's legacy whose major contribution is the type of exegesis she introduced after the i970s. However, one would also be right in affirming that post-colonial scholarship among a certain generation of Cameroonians has been influenced by Warnier's works, especially among those who had their training in the University of Yaoundé, scholars who would go on to teach and supervise students. This influence isreflected in their studies and can be observed in the models, conceptual frameworks and theories with which they armed their students. Conversely, the publications of the European scholars have also gained from the work of some of their African encounters. Some of the categories developed by Warnier are not only a reflection of field experiences but also a product of interaction with research students. By his own account, Warnier's L'Esprit d'Entreprise au Cameroun (Warnier, 1994) which stands in a critical relation to Dongmo (I98I) owes its initial inspiration to Warnier's late supervisee Mouaffo. 
Even as a retired professor, he has continued to be a direct influence through his regular appearances on juries of doctorate and habilitation candidates who are working on Cameroon. His authoritative influence continues to be felt in the shaping of scholarship on Cameroon's peoples and their dynamics. He is also impressed by his former students considering some of their own approaches as constituting a rupture with normal habitual discourses: "un changement de ton dans la historiographie de langue anglaise/a change in perspective in Anglophone historiography" (Warnier, 2003: 657). Teachers and students are thus interlinked in a cycle of continuity and discontinuity.

\section{Case studies: Revisiting Contentious Identities in the staggering legacy of colo- nial ethnography Overworking the Chamba-ness of Bali Nyong'a}

Richard Fardon, who has extensively researched the Chamba ( $f$. Fardon I988), revisited the question of a Chamba identity for Bali Nyong'a in two works which simultaneously show an intention to advance and a hesitation that pins him down in the orthodoxy inherited from the colonial era. This label has been used to refer to a variety of peoples in Cameroon and Nigeria. However, their identity has been the source of intense debate given that in its current spelling owes much to colonial labeling ${ }^{8}$. In Cameroon the ethnic groups which lay claim to such an identity are situated in two areas, to the North in the Faro and Deo Division and in the Grassfields in Mezam and Ngoketunja Divisions. Four of the five groups in the Grassfields (Bali Gam, Bali Gashu, Bali Gansin, Balikumbat) speak Mubako, a language of the same family as that of the Chamba of the Faro and Deo Divisions. The only group with a conspicuous difference is Bali Nyong'a which speaks Mungaka which belongs to the family of Pati-Nun languages. These differences are reflected in social organization and cultural practices. Given the stark differences in culture the question arises as to the verity of a claimed common identity.

In a contribution to intersections between history and anthropology in Cameroon studies Fardon (1996) had boldly questioned the assumed Chamba-ness as claimed for this ethnic group. He came back to this issue in a book on an institution of public culture (Fardon 2006), in which he adopts a completely novel approach, that of reading the history and identity of a people through performance and display in ceremony. Through a comparative approach the author succeeds in showing not only how there is a continuity between Chamba culture in the period preceding the Fulbe-led jihad in the Benue-Faro-Deo area of Cameroon and performances and elements of material culture within the Lela ceremony in Bali Nyong'a, but also how these have survived in other Chamba derived polities within the Cameroons Grassfields and Donga. He demonstrates how, with a minority core of Sama and Ndaganbila ${ }^{9}$, Bali Nyong'a, which is an authentic Grassfields polity with a model that resembles in most respects the Bamum kingdom ${ }^{10}$, claims exogenous origins from the northern border of Cameroon and Nigeria and ostenthemselves as Sama or Samba. 
tatiously exhibits a public culture that is Chamba. In the process of becoming Grassfields ("Grafi"), peoples claiming Chamba identity not only establish their own polities among earlier inhabitants, they integrate into the system of alliances between the polities of the Bamenda plateau such alliances being largely based on mutual animosity and competition over ascendancy. In the process of integration, the allies of the newcomers adopt and graft practices of the latter to their annual ceremonies; conversely, the newcomers adopt the cultural values of older settlers and graft them on to their own practices ( $f$. Engard, I989; Diduk, 1987; Yenshu Vubo, 2001, 2003). In this way, the autochthones share in the splendour of participating in a culture originating farther north (considered to be enriching) while the newcomers benefit from the normality of integrating diplomatically into their new context.

Fardon demonstrates the existence of elements of "pan-Chamba" identity far beyond the Grassfields which is the starting point in the analysis, but also implicitly demonstrates how this culture spills over into other groups (as in the Grassfields) and how it is forged in relation to other cultures within ever-changing environments (Fulbé-led jihad in Northern Nigeria and Cameroon, Grassfields, Donga area in Nigeria). What the book does not explain are the lingering enigmas surrounding the Chamba-ness of Bali Nyong'a enigmas that he had hinted at when treating the problematic relationship of the Chamba dynasty to the legendary Gawolbe, a relationship that is uterine rather than being characterised by patrilineal descent (Fardon, 1996: 30). Moreover, there are the multiple contrasts between, on the one hand, its affirmed and projected public culture with Chamba elements (lela, voma), and on the other, a generalized popular culture (language, social and political organization) that the people share with the constellation of speakers of Pati-Nun (subgroup 9 of East Grassfields Bantu within group 9 of the Atlas Linguistique du Cameroun). In an earlier examination of the question (Fardon, 1996:32) he had given the impression that the increasing projection of Chamba identity might well be seen as an "invention of tradition" in the sense of Hobsbawm, namely traditions "actually invented, constructed and formally instituted and those emerging in a less traceable manner within a brief period - a matter of a few years perhaps - and establishing themselves with great rapidity" (Hobsbawm, I992: I). He had even argued that " $[t]$ here were moments in its history when Bali-Nyonga could have equally or probably more plausibly set in train arguments for an identity other than it did" (Fardon, 1996: 32). This is exactly what transpires when the author shows the absence of an elaborate history of Chamba origins in Bali Nyong'a (although some consciousness of exogenous origins for elements of its population existed) prior to European deductions drawn from observed language distribution, a process which is also reported elsewhere in the Grassfields (Yenshu Vubo, 2001). The political motivations for the appropriation, elaboration and projection of such traditions, as demonstrated elsewhere for the manipulation of historical tradition among other Grassfields peoples (Yenshu Vubo, 200r, 2003; Yenshu and Ngwa, 200I), is evident. 
$[\mathrm{H}] \mathrm{ad}$ colonialism not occurred when it did, there is little reason to suppose that Bali-Nyonga would have become Chamba. Given another century, the claims to origins with the other five Bali Chiefdoms (had Mubako survived in all of them) might have been dropped, or retained in a fashion as perplexing to putative ethnographer/ historians of the early twenty-first century as the common claims to Tikar origins. [...] Of course, the Chamba-ness of Bali-Nyonga is a selective appropriation of the past (Fardon, 1996: 36).

However, in the more recent publication, Fardon appears less certain and unable to forcefully broach the point as to "whose representation of Chamba-ness Bali-Nyonga is" (ibid.) as he is careful not to challenge the orthodoxy of Chamba history for Bali. An institution such as Lela (much more than any other institution) was the key factor as it "sutured northern origins with a Grassfields identity through the re-enactment of might and wealth" (Fardon, 2006: 139). Whereas the northern origins which stands out as a superstructure (to speak in Marxist terms) is explored, the Grassfields substratum of a clear cut affinity with Nun speakers is explained away in terms of incorporation/borrowings ("more is more"), reorganization or speculations about adoption of the majority language (see also Gwanfogbe, I988; Lima 1988). Concerning the latter, Chilver (1995: 107) had argued that it could only have been a "lightning conversion of the conquerors by the conquered" ( $f$. also Gwanfogbe, op. cit.: 19-22).

One will then take the author to task for not looking at the history of the Grassfields component of the polity and what Lela and the projection of Chamba-ness do to it. In reading through Bali Nyong'a's official history and its recent exegesis impregnated as it is with a high dose of discourse about Chamba-ness and in contrasting this with its prominent Grassfields culture, one gets the impression that something is hidden or has been lost over the generations in which Chamba identity has been worked and reworked. In fact, by the time of Hutter's visit to Bali Nyong'a, it was not the Chamba but the Bamum kingdom (speakers of the pati-Nun group of languages) that was the model of social and political organization (Hutter, 1902) while one of its key institutions (voma) was imported from the other Bali groups in an apparent process of enhancement of Chamba-ness. If there has been a deliberate process of enhancing and affirming the dominant position of Chamba elements and the external distinctiveness of a "purported" Chamba identity in the colonial and post-colonial setting, the dynamic has also contributed to enhancing "organized oblivion" or "forced forgetting" (Connerton, 1989: 14) vis-à-vis a Grassfields character. This argument is derived from Fardon's own previous assertion that an alternative of considering Bali Nyong'a history in terms of a Grassfields successor state was also plausible (Fardon, 1996: 31). However, he stops short of exploring this alternative track and rather takes the now orthodox version (irrespective of its evident flaws) which was built around a colonial historiography premised on the pseudo-Hamitic theory of African civilisations then prevalent and replete in insinuations by colonial officers and travellers. Indeed, the latter is evident in German and British attitudes as Fardon himself had hinted: 
Early German sources used the term Bali and to note that the Bali came from the north, or southern Adamawa... Minimally, Bali seem to have been telling Zintgraff and subsequent German interlocutors that they were from the north and therefore distinct from the Grassfielders among whom they dwelt. In a variety of ways, northern origins may have been prestigious (ibid.: 32).

The precise period at which Bali chifdoms became definitely 'Chamba' in their own accounts is unclear... once the term became available, there was a two-stage crystallization of a sense of collective Chamba-ness, involving all five of the Bali chiefdoms, around the earliest and latest years of the British administration... Early British reports show that the Chamba connection [for Bali-Nyonga] had become conventional wisdom for District Officers - and presumably for Bali also (ibid.: 33 ).

This is the track that can be fruitfully pursued to provide an alternative examination of identities in which Chamba-ness and historicising within its frame will be largely a colonial invention which has only survived to the extent that it was useful in that regard. It was even a short-lived motive for what Jean-Loup Amselle (op. cit.: 85) calls "identity conversion", a process observable all over Africa in general and with peoples who were later to be called Chamba or Bali (Zeitlyn, op. cit.: 102). Changes in political contexts have dictated changes in identity claims from within Bali-Nyonga to the extent that the discussion on Chamba-ness (whether it is or it is not Chamba) is outmoded or a simple scholastic exercise. For local peoples, it had served its usefulness in the German version of Indirect Rule, had become problematic in the British period and may be no longer relevant. The narrative may be conventionally recited in text books and narrated uncritically in background statements to academic works but it no longer merits the passionate attention it once had in political terms. In other words, it is no longer a component of political capital. Bali-Nyonga is evidently seeking its place within the "concert" of Grassfields peoples as authentically one of them rather than one within foreign origins and an alien identity. It is therefore a frontline player in the local provincial politics of chiefdoms as a member of the North West Fons Union as it also seeks to project a so-called cultural identity for that region ${ }^{11}$. The chiefdom has even fallen under the influence of the autochthony creed that emerged in the 1990 as one of the pillars of ethnic politics in Cameroon. In a disastrous expedition against its satellite chiefdom of Bawock and bearing all of the characteristics of ethnic cleansing, one of the arguments advanced by ethnic chauvinists was that the latter were strangers as opposed to the dominant Bali-Nyonga who were autochthones ${ }^{12}$. In this way, one observes a conversion from the position of outsiders (people with a superiority because they have origins in the North) to that of insiders because this is an age in which autochthony pays in terms of official protection ${ }^{13}$. Grassfields and Cameroonian such as the large embroidered gowns and the Lela festival. sites this leading to the loss of property and lives. 
The grounds may now be fertile for exploring that insider perspective from the point of view of autochthony.

\section{Nebulous "Tikars"}

While the Tumu of the upper Mbam valley, situated to the west of the Adamawa plateau that divides Cameroon between north and south, are clearly identified today by the label of Tikar (although they do not refer to themselves as such), British colonial officers working in what is present day North West Province (initially known as Bamenda Division and then Bamenda Province) were in the habit of referring to a host of ethnic groups as the Bamenda Tikar. This name brought together those who stand astride the two major linguistic sub-groups of Grassfields Bantu, namely Mbam-Nkam (e.g. Bafut, Bambili, Bambui, Awing, Wimbum) and Ring (Kom, Nso, Babanki, groups in the Ndop plain) with no explanations as to the choice of the name. The major characteristic of this group was an alleged common history of migration from the North East in Tikar country. Later on anthropologists who came to work in this area took the label for granted and started to elaborate on it. Shortly after independence the question of such an identity became the object of debate. Some scholars argued that there were no such peoples (Jeffreys, 1963 ) while others, by dismissing these as claims from Bamenda chiefs in the search for political legitimization, argued it was a non-problem (Chilver and Kaberry, I97I: 13-14). By the I970s, David Price restricted this appellation to the Tumu or "six contiguous Tikar kingdoms" of the Upper region of the Mbam river but only as a Mbum nickname, the former not even using this appellation as a self-conscious label (Price, 1979: 89-98). Eldridge Mohammadou ( 1990 ) came to interpret claims to a certain Tikar identity by some western Grassfields kingdoms as the exportation of the Tikar model by Chamba invasions into the Grassfields, thus bringing together these two identities in a tradition that dates back to the colonial anthropology of Temple (1965: 80).

Parallel to these developments, the thesis of Tikar ethnogenesis had become one of the charter histories of local peoples and has come to be part of some collective consciousness, even gaining a new lease of life in the eastern Grassfields, namely among the Bamileke of the Nde and Mifi Divisions. This can be attributed to the difficulty to obliterate colonial models especially in a context where history is not of prime concern anymore. The interest in Tikar origins, ancestry or connections is coming from new and unexpected directions. With developments in biotechnology that open possibilities for tracing lost ancestry through comparative genetics, "African-Americans and agents of African-Americans who have traced their origins to the Tikar of Cameroon, would like to know about this group of people" (Nyamnjoh, 2007: I). In response, Nyamnjoh, in a much updated approach that strikes a balance between the orthodox claims of Tikar origins for the Grassfields and the realism of restricting the identity label to the peoples of the Upper Mbam valley, refers the curious Americans to Bamenda (it is not clear whether reference is made to the town or to the North West region referred to by some people

started complaining about non-native presence in their local spaces. This was sanctioned by a constitutional revision which promised to protect "indigenous minorities" (cf. Yenshu ig98, 2006). 
as Bamenda in colonial fashion), Fumban , Bankim and Ngambe. It is not unlikely that some of these new claimants will trace their ancestry to the Grassfields since the area was one of the principal attested sources of the trans-Atlantic slave trade (Chilver and Kaberry, 1965; Curtin and Vansina, 1964). However, this new link is a reflection of the recent transportation of this colonial myth to the Americas which is concomitant with the increasing presence of Cameroonians in the United States and the mix up in art promotion following Northern's insistent reference to some art of the North West Province of Cameroon as that of the "Bamenda Tikar" (Northern, 1973, 1979, I984). In the latter regard, there was even an exhibition of some art that was attributed to the Tikars in the USA in 2007.

The new claims are coming at a period when much of that identity has been debunked and situated within its colonial origins. Fowler and Zeitlyn (op. cit.: II) unmistakably situate the emergence of the Tikar claims at early stages of the British presence in Southern Cameroons, that is "in the administrative records of the I920s in the context of a new [...] colonial regime seeking to establish some form of effective administration". They, however, stop short of taking the argument to its logical end as they explore several other alternatives in purely speculative terms with no definite conclusion. The answer as we have seen above is in an ethno-racial classification that did not declare itself: a fascination with supposedly "superior" peoples of northern origins. As we have seen above the Chamba and Tikar categories occupy a central place in this colonial narrative. The two terms even converge in the scheme as the latter is made to be a branch of the former as can be seen in Temple (op. cit.: 8o) or as an amalgam as in the case of Kom (Jeffreys I953), a model which was replicated by Eldridge Mohamadou (1990).

The legacy of this colonial anthropology of identity has survived, so that, despite advances in research, its categories are strongly embedded in the imaginary of social thought. Walters Gam Nkwi (2010: 65), for instance, writes in a recent study in the following terms: "Bambili and Babanki-Tungoh belong to the Tikar ethnic group and speak the semi-Bantu language" (cf. also Gam Nkwi 20II). The following quote from a recent thesis is telling:

"Tikar is a name given to a group of villages in the Bamenda Grassfields with segmentary lineage system whereby smaller units of the ethnic groups (or villages) are headed by Fons, but all Tikars are related to the same ancestors. ... Bambili and Babanki-tungoh are Tikar villages and they share a common boundary" (Tangie 2007: 2).

Perrois and Notué (2007: 27) even refer to some ethnic groups as "ndobo-tikars". The schemas are also reworked in different directions to integrate conflicting colonial categories such as those of the Widekum and Tikar. Some scholars are situating Bambili, once classified as Tikar, within the equally problematic category of the Widekum (no longer widely in use) while Mankon is claiming a Tikar origin which is some distance from its Widekum earlier classificatory scheme (Notué 2008). Other narratives integrate both perspectives where Bambili is presented as: “... a breakaway village of the Tikari 
tribe that migrated from northern Cameroon and settled in Ndop. They were supplanted by another larger migrant group from Widekum that has hitherto been the ruling family in Bambili" (Ayuninjam 1998: 6). These lingering colonial labels do not reflect the advances in the social sciences and humanities (archaeology, linguistics, anthropology and history), which are calling for new approaches. Unfortunately, the paths traced by the joint efforts of both European and local researchers, as we saw above, have not been pursued vigorously.

\section{Conclusions}

The survival and even the renewal of the imaginary of colonial classification has also been reported elsewhere. Vidal (I999: I82) remarks that despite the fact that the much problematic Hutu-Tutsi classification had been the subject of intense criticism based on first hand ethnographic and archival research, the model had not been disqualified by the time she wrote. In the same vein, Chrétien (op. cit.: 139) has also lamented the persistence of categories such as "Bantu" and "Hamitic" despite a radical critique of their content and origins. The blame for such attitudes can be attributed to the lack of communication between the world of scientific research and other media of dissemination (elementary and secondary school teaching either through the classroom, textbooks and the mass media) as well as the limited communication between foreign scholars and local researchers either within the same generation or across generations.

The generation of one-directional scholarship from Europe to Cameroon is almost over. "Almost over" because while on the decline it is still active in Cameroon ( $f$. Warnier 2008). Luckily enough some of the former students have come of age as anthropologists in their own right (Fokwang 2005). Fokwang (2005: 190) argues that this new breed "has the potential to reproduce or, perhaps, transform the legacy of diverse anthropological traditions in Cameroon" despite the fact that there is still a "crying need for indigenous anthropologists". What remains to be ascertained is whether there shall be continuity in the pioneering efforts. As for Mrs. Chilver, her epoch is evidently over and her legacy is firmly established although issues she raised are far from resolved. This is concomitant with the development of sociologies and anthropologies from within Cameroon that are ready to meet new preoccupations with identity and ethnicity. The latter have shifted from essentialism (an "ethnicity of the ethnic group") to issues of ethno-regionalism and questions of marginalization (autochthony, minority rights) in which both Europeans and African find common collaborative grounds (cf. Konings and Nyamnjoh, 2000; Gieschere and Nyamnjoh, 2000). Inspired by the works of both Mrs Chilver and Warnier, one can argue for a comparative study of social institutions in a model that is transethnic and that matches genetic variability and geological evidence (as concrete data from different directions) with social narratives (oral history, myths, legends) (Yenshu Vubo, 2009: 158I60). There are also newer arguments that militate in favor of treating identities as "situational variables" (Yenshu Vubo and Ngwa, 2001: 185) or as "complex, negotiated and relational experiences that call for a nuanced rather than essentialist articulation of identity and belonging" (Nyamnjoh, 2007: 8). New preoccupations are therefore calling for novel approaches and theoretical perspectives as well as new collaborations. In this case, an- 
thropology does not "come home from the tropics in order to rejoin the anthropology of the modern world that is ready and waiting" (Latour, I993: 100); that is, the anthropology that comes home from its former expectations in the colonial epoch. Anthropology is now appropriated by a new generation of indigenous sociologist-anthropologists grappling with novel realities as they inform and are joined in a new search by others whether they are European, American or Japanese. In this process, a sociology-anthropology from within comes face-to-face with a decolonized postcolonial anthropology from without.

\section{References}

Aletum, T. M. (1971). Appraisal of our Culture: Social Customs and Traditions of the Bafut, West Cameroon. Pontifical Urban University, Rome.

- (1974). Political Conflicts within the Traditional and Modern Institutions of the Bafut, Cameroon. Louvain: Vander.

Amselle J. L. (1990). Logiques métisses. Anthropologie de l'identité en Afrique et ailleurs. Paris: Payot.

Amin, S. (1998). "Ethnicity: Assault on the Nation", In: C. Uroh, (ed.), Africa and the Challenge of Development. Essays by Samir Amin, Ibadan: Hope Publications, pp. 48-72.

Ayuninjam, F. F. (1998). A Reference Grammar of Mbili. Lanham, Maryland: University Press of America.

Barbier, J.- CI. (1978). “Notes sur les relations entre les populations Bamileke et les Bandem”, ONAREST Scientific Papers, Vol. I, No. 2, pp. 45-52.

- (198I). Le peuplement de la partie méridionale du Plateau bamileké. In: C. Tardits (ed.).

- (1981). The Contribution of Ethnological Research to the History of Cameroon's Cultures, Paris: CNRS. Colloques Internationaux du CNRS. No 55I Vol II., pp. 33I-353.

Casentini, G. (2008). Labelling, appointing and naming as political tools. Legacies of British colonial language in northern Ghana, paper presented at the conference on Africa's Development: Possibilities and Constraints, Moscow, 22-24 May 2008.

Chilver, E. M. (1981). Chronological Synthesis: The Western Region, comprising the Grassfields, Bamum, the Bamileke chiefdoms and Central Mbam. In C. Tardits (ed.), The Contribution of Ethnological Research to the History of Cameroon's Cultures, Paris : CNRS. Colloques Internationaux du CNRS. No 55I Vol II, pp. 453-473.

- (1990). Working Notes. Dr. Engard's Bafut Myths: Some Earlier Anecdotal Material, Privately circulated.

- (1995). Letter to V. G. Fanso, Journal of the Anthropological Society of Oxford, Vol. 26, No. 1,pp. 105 -IIO.

Chilver, E. \& Kaberry, P. M. (1963a). The Peoples of Bamenda. Cameroon Students Journal, Vol. I, 1963, pp. $5-8$.

- (1963b). Notes and Queries on Historical Research in the Grassfields. Abbia, No. 4, pp. 119-133.

- (1967a). Traditional Bamenda. The Precolonial History and Ethnography of the Bamenda Grassfields. Vol. I. Buea: Ministry of Primary Education and Social Welfare and West Cameroon Antiquities Commission.

(1967b). The Kingdom of Kom in West Cameroon. In D. Forde \& P.M. Kaberry (eds.), West Africa Kingdoms in the Nineteenth Century, Oxford: Oxford University Press for the International African Institute, pp.123-151.

- (1970). Chronology of the Bamenda Grassfields. Journal of African History, Vol. II, No. 2, pp. 249-257.

- (1971). The Tikar Problem: A non-Problem. Journal of African Languages, Vol. 10, No. 2, pp. 13-14.

Chrétien, J. - P. (1999). Hutu et tutsi au Rwanda et au Burundi. In: J. L. Amselle and E. M'Bokolo (eds.) Au Cour de l'Ethnie. Ethnie, Tribalisme et Etat en Afrique, Paris : La Découverte et Syros, pp. 129-165.

Connerton, P., (1989). How Societies Remember. Cambridge: Cambridge University Press. 
Curtin, J. P. and Vansina, J. (1974). Sources of the Nineteenth Century Slave Trade. Journal of African History. Vol. 5. No. 2, pp. $185-208$.

Diduk, S.E. (1897). The Paradox of Secrets: Power and Ideology in Kedjom Society. Indiana University PhD. Thesis.

De Souza, A. R. \& Porter, P.W. (1974). The Underdevelopment and Modernization of the Third World. Washington, D. C.: Association of American Geographers, Resource Paper, 28.

Engard, R.K. (1989). Dance and Power in Bafut (Cameroon). In: W. Arens \& I. Karp, (eds.) Creativity of Power: Cosmology and Action in African Societies, Washington D.C.: Smithsonian Institution Press, pp. 129162.

Dongmo, J. L. (1981). Le Dynamisme bamileké. Yaoundé : CEPER.

Dozon, J.-P. (1999). Les Bété: création coloniale. In: J. L. Amselle and E. M'Bokolo (Eds.). Au Cơur de l'Ethnie. Ethnie, Tribalisme et Etat en Afrique. Paris : La Découverte \& Syros, pp. 49-85.

Fardon, R. 1988. Raiders and Refugees: Trends in Chamba Political Developments, 1750-1950. Washington: Smithsonian Institution Press.

- (1996). The Person, Ethnicity and the Problem of 'Identity'. In: I. Fowler and D. Zeitlyn (eds.), African Crossroads: Intersections between History and Anthropology in Cameroon. Oxford: Bergahn, pp. 17-44.

- (2006). Lela in Bali: History through Ceremony in Cameroon. New York and Oxford: Berghahn.

Gam Nkwi, W. (2010). Sons and Daughters of the Soil: Land and Boundary Conflicts in North West Cameroon, 19552005. Bamenda: Langaa.

(2011). Voicing the Voiceless: Contributions to Closing the Gaps in Cameroon's History. 1958-2009. Bamenda: Langaa.

Gwanfogbe, M. (1988). Geographical and Historical Introduction of Bali Nyong'a. In: V. Titanji, Mathew Gwanfogbe, Elais Nwana, Gwandwa Ndangam and Adolf Lima Sema (eds.), An introduction to the study of Bali Nyong'a, Yaoundé: Stardust, pp. 9-42.

Gieschiere, P. and Nyamnjoh, F. (2000). Capitalism and Autochthony: The Seesaw of Mobility and Belonging. Public Culture, Vol. 12, No. 2, pp. 423-425.

Hobsbawm, E. (1992). Introduction: Inventing Traditions. In E. Hobsbawm \& T. Ranger (eds.). The Invention of Tradition. Cambridge: Cambridge University Press, pp. I-I4.

Hyman, L. M. \& Voorhoeve, J. (eds.). (1974). Symposium on patterns in language and society: sub-Saharan Africa. 6th Conference on African Linguistics. Columbus, Ohio.

- (1980). Les Classes Nominales dans le Bantou des Grassfields. L'Expansion Bantoue, I. Paris : SELAF/Colloques Internationaux du CNRS.

Hutter, F. (1902). Wanderungen und Forschungen in NordHinterland von Kamerun. Braunschweig: Friedrich Viewig und Sohn.

Jeffreys, M. D. W. (1953). Some Notes on the Bikom. The Eastern Anthropologist, Vol. 4, No. 2.

- (1963). Who are the Tikars? African Studies, Vol. 21, No. 2, pp. I4I-153.

- (1972). Some African Tribal Names. Journal of the Royal African Society, Vol. 4I, 1972, pp. 47-49.

Journal of the Anthropological Society of Cameroon of Oxford (1995). Biography of Sally Chilver. JASO, Vol. 26, No. I, pp. III-117.

Konings, P. \& Nyamnjoh, F. B. (200o). Construction and Deconstruction: Anglophones or Autochthones. The African Anthropologist, Vol. 7, No. I, pp. 5-32.

- (2003). Negotiating an Anglophone Identity. A Study of the Politics of Recognition in Cameroon. Leiden, London: Brill.

Latour, Bruno. (1993). We have never been modern. New York: Harvester Wheatsheef.

Lima, A. (1988). Mungaka: its Development, Spread and Use. In: V. Titanji, Mathew Gwanfogbe, Elais Nwana, Gwandwa Ndangam and Adolf Lima Sema (eds.), (1988), An introduction to the study of Bali Nyong'a. Yaounde: Stardust, pp. $111-158$.

Mamdani, M. (2002). When Victims become Killers: Colonialism, Nativism and the Genocide in Rwanda. Kampala: Fountain Publishers. 
Maupeu, H. (1990). L'administration indirecte, les méthodistes et la réforme de l'identité Moru (Kenya), 1933-1963. Recueils est-africains I, Centre d'Etudes africaines, Ecole des Hautes Etudes en Sciences sociales (EHESS), Paris.

Mohammadou, E. (1990). Traditions historiques des peuples du Cameroun central. Tokyo: ILCAA.

Nkwi, P.N. (1973). A Clanship Study: A Systematic Study of Clans in Kom. Unpublished mimeograph, Faculté des Lettres, Fribourg.

- (1974). The Problem of the Origins of Kom Matrilineal Institutions. In: Final Report of Symposium Leo Frobenius on 'Perspectives of Contemporary African Studies', organized by the German and Cameroon Commissions for UNESCO, 3-7 December 1973. Kohn: Deutsche UNESCO-Kommission, pp. 282- 297.

- (1976). Traditional Government and Social Change: A Study of the Political Institutions among the Kom of the Cameroon Grassfields. Fribourg: The University Press, Studia Ethnographica Friburgensia.

- (1987). Traditional Diplomacy. A study of inter-chiefdom relations in the Western Grassfields, North West Province, Cameroon. Yaounde: Publications of the Department of Sociology, University of Yaoundé.

Nkwi, P. N. and Socpa, A. (2007). The Teaching of Anthropology in the University of Yaounde I. The African Anthropologist, Vol.14, No. I \& 2, pp. 65-88.

Nkwi, P. N. \& Warnier, J. P. (1982). Elements for a History of the Western Grassfields. Publications of the Department of Sociology and Anthropology, University of Yaoundé.

Northern, T. (1973). Royal Art of Cameroon: the Art of the Bamenda Tikar. Hanover, N. H. 1979. Splendour and Secrecy: Art of the Cameroon Grassland. New York: Page Primitive and Ancient Art.

- (1984). The Art of Cameroon. Washington, D. C.: Smithsonian Institution Press.

Notué, J. P. (2008). Introduction. In: J. P. Notué (ed.), Mankon: Arts, Heritage and Culture from the Mankon Kingdom. 5 Continents Publications.

Nyamnjoh, F. (2007). African Americans seeking Tikar Origins in Cameroon.

http://.www.nyamnjoh.com/africanamerican_search_tikar_origins.pdf

Otayek, R. (200I). LAfrique au prisme de l'ethnicité : perspective française et actualité du débat. La Revue internationale et stratégique, Vol. 43, No. 129, pp. I-I4.

Perrois, L. and Notué, J. P. (1997). Rois et sculpteurs de l'Ouest: la panthère et la mygale. Paris : Kharthala.

Price, D. (1979). Who Are the Tikar Now? Paideuma, Vol. 21, pp. 89-98.

Tangie, E. N. (2007). From Friends to Enemies: Inter-Ethnic conflicts amongst the Tikars of the Bamenda Grassfields (North West Province of Cameroon) C. 1950-1998. M. Phil. Thesis, Faculty of Social Sciences, University of Troms $\phi$, Norway, 2007.

Tardits, C. (1960). Contributions à l'Étude des Populations Bamileké. Paris: Berger-Levrault.

- (1980). Le Royaume Bamoum. Paris : EDISEM/Publications de la Sorbonne/Armand Colin.

- (1981). Rapport de synthèse: L'implantation à l'ouest. In: C. Tardits (ed.). Contribution de la recherche ethnologique à l'histoire des civilisations du Cameroun. Paris : Colloques Internationaux du CNRS 55I, No. II, pp. 457-486.

Temple, C. L. (ed.). (1965). Notes on the Tribes, Provinces, Emirates and States of the Northern Provinces of Nigeria by 0 . Temple. London: Frank Cass and Co. Ltd.

Titi Nwel, P. (1989). L'Enseignement et la pratique de l'anthropologie au Cameroun. Paper presented at the first conference on African anthropology, Yaoundé, 3-6 September 1989.

Vidal, C. (1999). Situations ethniques au Rwanda. In J. L. Amselle and E. M'Bokolo (eds.), Au Cour de l'Ethnie. Ethnie, Tribalisme et Etat en Afrique, Paris : La Découverte et Syros, pp. 167-184.

Warnier, J. P. (1975). Precolonial Mankon : the Development of a Cameroon Chiefdom in its Regional Setting. PhD. dissertation, University of Pennsylvania.

- (1974). L'histoire précoloniale de la Chefferie de Mankon. Département de Mezam. In: C. Tardits (ed). La Contribution de la Recherche Ethnologique à l'Histoire des Civilisations du Cameroun. Paris: CNRS. Colloques Internationaux du CNRS. No 55I Vol II, pp. 421-436. 
- (1982). Archóologie et Histoire du Cameroun : le cas de l'Ouest. Cahiers de Sociologie (Department of Sociology, University of Yaoundé), No. I, March, pp. 13-17.

- (1983). Sociologie du Bamenda précolonial, Cameroun. Doctorat d'État thesis, Université de Paris X.

- (1984). L'histoire du peuplement et genèse des paysages dans l'Ouest camerounaise. Journal of African History, Vol. 25, December, pp. 395-410.

_ (1985). Échanges, Développement et Hiérarchies dans le Bamenda précolonial. Stuttgart: Franz Sterner Verlag.

- (1994). L'Esprit d'Enterprise au Cameroun. Paris : Karthala.

- (2003). Review of Abega, Séverin Cécile's Société civile et réduction de la pauvreté \& Les Choses de la forêt. Les masques des princes tikars de Nditam \& Yenshu Vubo's . In Cahiers d'Etudes africaines, Vol. 43, No. 3, pp. 657-659.

- (2008). Regner au Cameroun. Le Roi-Pot. Paris: Karthala.

Yenshu Vubo, E. (200I). Itinerant Craftsmen, Highland Farmers and Royal Herdsmen: Interpretation of Kedjom Historical Traditions. Limbe: Studies in the History and Anthropology of Cameroon's Peoples I. Design House.

- (2003). Levels of Historical Awareness. The Development of Identity and Ethnicity in Cameroon. Cahiers d'Etudes Africaines, Vol. 43, $\mathrm{N}^{\circ}$ 3, pp. 591-628.

- (2009). Tradition et Modernité au Cameroun. Autour de la Transethnicité. Mémoire d'Habilitation à Diriger des Recherches. Université de Franche-Comté, Besançon.

Yenshu Vubo, E. and Ngwa, G. N. (200I). Changing inter-community relations and the Politics of identity in the Northern Mezam Area. Cahiers d'Etudes Africaines, Vol. 4I, No. I, 2001, pp. I63-190.

Zeitlyn, D. (1995). Eldridge Mohammadou on Tikar Origins. Journal of the Anthropological Society of Oxford, Vol. 26, No. 1, pp. 99-104. 